\title{
Genomic landscape of salivary gland tumors
}

\author{
Shumei Kato ${ }^{1}$, Sheryl K. Elkin ${ }^{2}$, Maria Schwaederle ${ }^{3}$, Brett N. Tomson ${ }^{2}$, \\ Teresa Helsten ${ }^{3}$, Jennifer L. Carter ${ }^{2}$, Razelle Kurzrock ${ }^{3}$ \\ ${ }^{1}$ Department of Investigational Cancer Therapeutics, The University of Texas MD Anderson Cancer Center, Houston, TX, USA \\ ${ }^{2} \mathrm{~N}$-of-One, Inc., Lexington, MA, USA \\ ${ }^{3}$ Center for Personalized Cancer Therapy and Division of Hematology and Oncology, Department of Medicine, UC San Diego, \\ Moores Cancer Center, La Jolla, CA, USA
}

Correspondence to:

Shumei Kato, e-mail: Skato@mdanderson.org

Keywords: salivary gland tumor, next-generation sequencing, genomic landscape, personalized therapy, targeted therapy

Received: April 25, $2015 \quad$ Accepted: July 15, $2015 \quad$ Published: July 27, 2015

\section{ABSTRACT}

Effective treatment options for advanced salivary gland tumors are lacking. To better understand these tumors, we report their genomic landscape. We studied the molecular aberrations in $\mathbf{1 1 7}$ patients with salivary gland tumors that were, on physician request, tested in a Clinical Laboratory Improvement Amendments (CLIA) laboratory (Foundation Medicine, Cambridge, MA) using next-generation sequencing (182 or 236 genes), and analyzed by $\mathrm{N}$-of-One, Inc. (Lexington, MA). There were 354 total aberrations, with 240 distinct aberrations identified in this patient population. Only 10 individuals $(8.5 \%)$ had a molecular portfolio that was identical to any other patient (with four different portfolios amongst the ten patients).

The most common abnormalities involved the TP53 gene (36/117 [30.8\% of patients]), cyclin pathway (CCND1, CDK4/6 or CDKN2A/B) $(31 / 117$ [26.5\%]) and PI3K pathway (PIK3CA, PIK3R1, PTEN or AKT1/3) (28/117 [23.9\%]). In multivariate analysis, statistically significant co-existing aberrations were observed as follows: TP53 and ERBB2 $(p=0.01)$, cyclin pathway and MDM2 $(p=0.03)$, and PI3K pathway and HRAS $(p=0.0001)$. We were able to identify possible cognate targeted therapies in most of the patients $(107 / 117$ [91.5\%]), including FDA-approved drugs in 80/117 [68.4\%]. In conclusion, salivary gland tumors were characterized by multiple distinct aberrations that mostly differed from patient to patient. Significant associations between aberrations in TP53 and ERBB2, the cyclin pathway and MDM2, and HRAS and the PI3K pathway were identified. Most patients had actionable alterations. These results provide a framework for tailored combinations of matched therapies.

\section{INTRODUCTION}

Malignant salivary gland tumors are an uncommon subgroup of head and neck cancers [1-3]. The most frequent types of malignant salivary gland tumors according to the WHO classification [1] are mucoepidermoid carcinoma (10.0-32.7\%) and adenoid cystic carcinoma $(23.3-23.8 \%)[4,5]$.

Initial standard of care therapy of localized disease is surgery and/or radiation therapy, whereas chemotherapy is typically reserved for palliative treatment of local and regional recurrence or metastatic disease [6]. Due to the rarity of the disease, data are often derived from case reports and retrospective series, rather than prospectively performed clinical trials. Thus, it has been challenging to define the role of chemotherapy in management of advanced salivary gland tumors [6]. Systemic therapies investigated in the past include cisplatin [7], paclitaxel [8], combination of cisplatin plus vinorelbine [9] and the combination of cisplatin, doxorubicin and cyclophosphamide [10]. Modest response rates can be achieved with cytotoxic chemotherapy ( $4 \%$ to $27 \%$ ) [7-10] and no drugs are approved by the Food and Drug Administration (FDA) specifically for salivary gland tumors.

Importantly, several possible biological targets in salivary gland tumors have been reported: c-Kit[11] 
(positive protein expression by immunohistochemistry but no exon 11 or 17 mutations); EGFR [12], HER2 [13, 14], androgen, estrogen and progesterone receptor protein expression by immunohistochemistry [15]; and PIK3CA [16] and $B R A F$ mutations [16]. Interestingly, salivary duct carcinomas resemble breast cancer histologically, and about 20 to $80 \%$ of salivary duct carcinomas are HER2 positive by immunohistochemistry [13, 14]; in approximately $90 \%$ of salivary duct carcinomas, androgen receptors are positive by immunohistochemistry [17].

Although targeted therapies with imatinib [18], gefitinib [19], cetuximab [20], trastuzumab [21] and lapatinib [22] have generally had low response rates, these therapies were given to unselected patients rather than matched to individuals whose tumors harbored cognate aberrations [18-22]. However, when patients were selected for the presence of ERBB2/HER2 or PIK3CA aberrations and were treated with appropriate targeting agents (trastuzumab and lapatinib [23] or mTOR inhibitors [24], respectively), anecdotal remarkable responses have been described.

Given that effective treatment options are needed, further molecular understanding of salivary gland tumors is necessary. We therefore examined the genomic landscape of salivary gland malignancies, as determined by targeted next-generation sequencing (NGS). Here we report the most frequent aberrations, many of which could conceivably be actionable with targeted therapies.

\section{RESULTS}

\section{Genetic aberrations in salivary gland tumors (Table 1, Figure 1 and Supplemental Table 1)}

Among all salivary gland tumors $(N=117)$ that were evaluated, $41.9 \%(49 / 117)$ of samples were histologically diagnosed as adenoid cystic carcinoma. The second most common histology was adenocarcinoma, not otherwise specified (NOS) (39.3\% [46/117]) followed by acinic cell carcinoma (6.0\% [7/117]), mucoepidermoid carcinoma $(4.3 \%$ [5/117]), salivary duct carcinoma (3.4\% [4/117]), myoepithelial carcinoma (2.6\% [3/117]) and undifferentiated carcinoma (2.6\% [3/117]) (Table 1).

The most common aberration among all salivary gland tumors was in the TP53 gene (36/117 patients [30.8\%]), followed by anomalies in the cyclin pathway $(C C N D 1, C D K 4 / 6$ or $C D K N 2 A / B$ ) (observed in $26.5 \%$ [31/117] of all salivary gland tumors). Aberrations in the PI3K pathway (PIK3CA, PIK3R1, PTEN or $A K T$ ) were the third most common set of aberrations among all salivary gland tumors $(28 / 117$ [23.9\%]). Anomalies in $H R A S$ were seen in $11.1 \%(13 / 117)$ of salivary gland tumors, including 5 of 46 patients $(10.9 \%)$ with adenocarcinoma, NOS (Table 1 and Figures $1 \mathrm{~A}$ and $1 \mathrm{C}$ ). Aberrations in
$E R B B 2$ were found only in patients with adenocarcinoma, NOS (7/46 patients [15.2\%] [two mutations and five amplifications]) (Table 1 and Figure 1C).

Molecular characteristics of patients with adenocarcinoma, NOS $(N=46)$ were similar to those of all salivary gland tumors (Table 1 and Figures $1 \mathrm{~A}$ and $1 \mathrm{C}$ ), likely because they were the second most common subgroup. The most common genetic aberrations among patients with adenoid cystic carcinoma $(N=49)$ were NOTCH1/2 (26.5\% [13/49]) (mainly NOTCH1 (24.5\% [12/49])) and KDM6A (26.5\% [13/49]). Aberrations in the PI3K pathway represent the second most common genetic alterations in adenoid cystic carcinoma patients (16.3\% [8/49]) (Table 1 and Figure 1B).

\section{Number of genetic aberrations and possible cognate targeted therapies in patients with salivary gland tumors (Figure 2, Supplemental Tables 1 and 2)}

Of the 354 total aberrations (some aberrations were identified in more than one case), 257 (72.6\%) were actionable, with $107 / 117$ patients $(91.5 \%)$ having a potentially actionable abnormality. Of the 240 distinct aberrations, 155 (64.6\%) were potentially actionable. Of these 155 actionable aberrations, 114 (47.5\% [114/240]) were targetable by an FDA-approved drug (off label). An additional 41 (17.1\% [41/240]) were targetable by an experimental drug in a clinical trial. The number of genetic aberrations reported per patient ranged from zero to ten with a median of three aberrations per patient (Figure 2). The number of genetic aberrations that were actionable ranged from zero to ten with a median of two actionable aberrations per patient (Figure 2). Of the 107 patients with at least one actionable aberration, 80 (74.8\%) had an aberration targetable by an FDA-approved drug and an additional $27(25.2 \%)$ had an aberration targetable by an investigational drug in a clinical trial (Supplemental Tables 1 and 2).

\section{Number of genomic aberrations and the distinctness of the profiles}

As mentioned, there were 240 distinct molecular alterations. Only ten patients (8.5\% [10/117]) had a molecular portfolio identical to at least one other patient (Supplemental Table 1, Case No. 13 and 1297 ([both adenocarcinoma, not otherwise specified]; No. 1523 and 1777 [both adenocarcinoma, not otherwise specified]; No. 3808, 4033, 4051 and 5681 [first three cases with acinic cell carcinoma and last past patient had adenocarcinoma, not otherwise specified]; and No. 1169 and 2807 [both adenoid cystic carcinoma] were identical). If we considered the molecular portfolio at 
Table 1: Baseline characteristics of salivary gland tumors and frequently associated genetic aberrations

\begin{tabular}{|c|c|c|c|c|c|c|c|c|}
\hline $\begin{array}{l}\text { Genetic } \\
\text { aberrations* }\end{array}$ & $\begin{array}{c}\text { All } \\
N=117 \\
\text { No. }(\%)\end{array}$ & $\begin{array}{c}\text { Adenoid } \\
\text { cystic } \\
\text { carcinoma } \\
N=49 \\
\text { No. }(\%)\end{array}$ & $\begin{array}{c}\text { Adeno- } \\
\text { carcinoma, } \\
\text { not } \\
\text { otherwise } \\
\text { specified } \\
N=46 \\
\text { No. }(\%)\end{array}$ & $\begin{array}{c}\text { Aciniccell } \\
\text { carcinoma } \\
N=7 \\
\text { No. }(\%)\end{array}$ & $\begin{array}{c}\text { Muco- } \\
\text { epidermoid } \\
\text { carcinoma } \\
N=5 \\
\text { No. }(\%)\end{array}$ & $\begin{array}{c}\text { Salivary } \\
\text { duct } \\
\text { carcinoma } \\
N=4 \\
\text { No. }(\%)\end{array}$ & $\begin{array}{c}\text { Myoepithelial } \\
\text { carcinoma } \\
N=3 \\
\text { No. }(\%)\end{array}$ & $\begin{array}{c}\text { Un- } \\
\text { differeniated } \\
\text { carcinoma } \\
N=\mathbf{3} \\
\text { No. }(\%)\end{array}$ \\
\hline $\begin{array}{l}\text { TP53 } \\
(N=36)\end{array}$ & $\begin{array}{c}36 \\
(30.8)\end{array}$ & $7(14.3)$ & $23(50.0)$ & $1(14.3)$ & $2(40.0)$ & $2(50)$ & $0(0)$ & $1(33.3)$ \\
\hline $\begin{array}{l}\text { Cyclin pathway } \\
(N=31)\end{array}$ & $\begin{array}{c}31 \\
(26.5)\end{array}$ & $6(12.2)$ & $16(34.8)$ & $5(71.4)$ & $1(20.0)$ & $0(0)$ & $1(33.3)$ & $2(66.7)$ \\
\hline $\begin{array}{l}\text { PI3K pathway } \\
(N=28)\end{array}$ & $\begin{array}{c}28 \\
(23.9)\end{array}$ & $8(16.3)$ & $12(26.1)$ & $1(14.3)$ & $2(40.0)$ & $4(100)$ & $1(33.3)$ & $0(0)$ \\
\hline $\begin{array}{l}\text { NOTCH1/2 } \\
(N=20)\end{array}$ & $\begin{array}{c}20 \\
(17.1)\end{array}$ & $13(26.5)$ & $6(13.0)$ & $0(0)$ & $0(0)$ & $0(0)$ & $1(33.3)$ & $0(0)$ \\
\hline $\begin{array}{l}\text { PIK3CA } \\
(N=16)\end{array}$ & $\begin{array}{c}16 \\
(13.7)\end{array}$ & $3(6.1)$ & $8(17.4)$ & $1(14.3)$ & $1(20.0)$ & $2(50)$ & $1(33.3)$ & $0(0)$ \\
\hline $\begin{array}{l}\text { KDM6A } \\
(N=14)\end{array}$ & $\begin{array}{c}14 \\
(12.0)\end{array}$ & $13(26.5)$ & $1(2.2)$ & $0(0)$ & $0(0)$ & $0(0)$ & $0(0)$ & $0(0)$ \\
\hline $\begin{array}{l}\text { ARID1A } \\
(N=13)\end{array}$ & $13(11.1)$ & $7(14.3)$ & 5 (10.9) & $0(0)$ & $1(20.0)$ & $0(0)$ & $0(0)$ & $0(0)$ \\
\hline $\begin{array}{l}\text { HRAS } \\
(N=13)\end{array}$ & $13(11.1)$ & $2(4.1)$ & $5(10.9)$ & $1(14.3)$ & $1(20.0)$ & $2(50)$ & $2(66.7)$ & $0(0)$ \\
\hline $\begin{array}{l}\text { BAP1 } \\
(N=10)\end{array}$ & $10(8.5)$ & $4(8.2)$ & $3(6.5)$ & $1(14.3)$ & $2(40.0)$ & $0(0)$ & $0(0)$ & $0(0)$ \\
\hline $\begin{array}{l}\text { MDM2 } \\
(N=10)\end{array}$ & $10(8.5)$ & $2(4.1)$ & 7 (15.2) & $0(0)$ & $0(0)$ & $0(0)$ & $0(0)$ & $1(33.3)$ \\
\hline $\begin{array}{l}\text { PTEN } \\
(N=10)\end{array}$ & $10(8.5)$ & $2(4.1)$ & $5(10.9)$ & $0(0)$ & $2(40.0)$ & $1(25)$ & $0(0)$ & $0(0)$ \\
\hline $\begin{array}{l}\text { NF1 } \\
(N=8)\end{array}$ & $8(6.8)$ & $0(0)$ & $6(13.0)$ & $1(14.3)$ & $1(20.0)$ & $0(0)$ & $0(0)$ & $0(0)$ \\
\hline $\begin{array}{l}\text { ERBB2 } \\
(N=7)\end{array}$ & $7(6.0)$ & $0(0)$ & $7(15.2)$ & $0(0)$ & $0(0)$ & $0(0)$ & $0(0)$ & $0(0)$ \\
\hline
\end{tabular}

${ }^{*}$ Genetic aberrations with $N \geq 7$ are reported.

${ }^{*}$ Cyclin pathway aberrations included $C C N D 1, C D K 4 / 6$ or $C D K N 2 A / B$ aberrations.

${ }^{*} \mathrm{PI} 3 \mathrm{~K}$ pathway aberrations included $P I K 3 C A, P I K 3 R 1, P T E N$ or $A K T 1 / 3$ aberrations.

the level of the gene, rather than the specific aberration (i.e., different abnormalities in the same gene would be considered identical), then the total number of genes altered across this cohort was 83 and, in that case, 20 patients $(17.1 \%$ [20/117]) had an identical molecular portfolio to at least one other patient (Supplemental Table 1, Case No. 13 and 1297; No. 1169 and 2807; No. 1523 and 1777; No. 1939 and 6651; No. 1975 and 5730; No. 2085 and 6718; No. 2901 and 4533; No. 3808, 4033, and 5681; and No. 4332 and 4731 were identical).
Association between TP53 and co-existing molecular aberrations in patients with salivary gland tumors. Univariate and multivariate analysis (Table 2)

In univariate analysis, NF1 aberrations were found to be significantly associated with TP53 aberrations (6 of 8 patients [75.0\%] with aberrant NF1 had a TP53 aberration; 30 of 109 patients [27.5\%] with normal NF1 had a TP53 aberration; $p=0.01$ ). Anomalies in the PI3K 
A. Genetic aberrations in patients with salivary gland tumors $(N=117)$

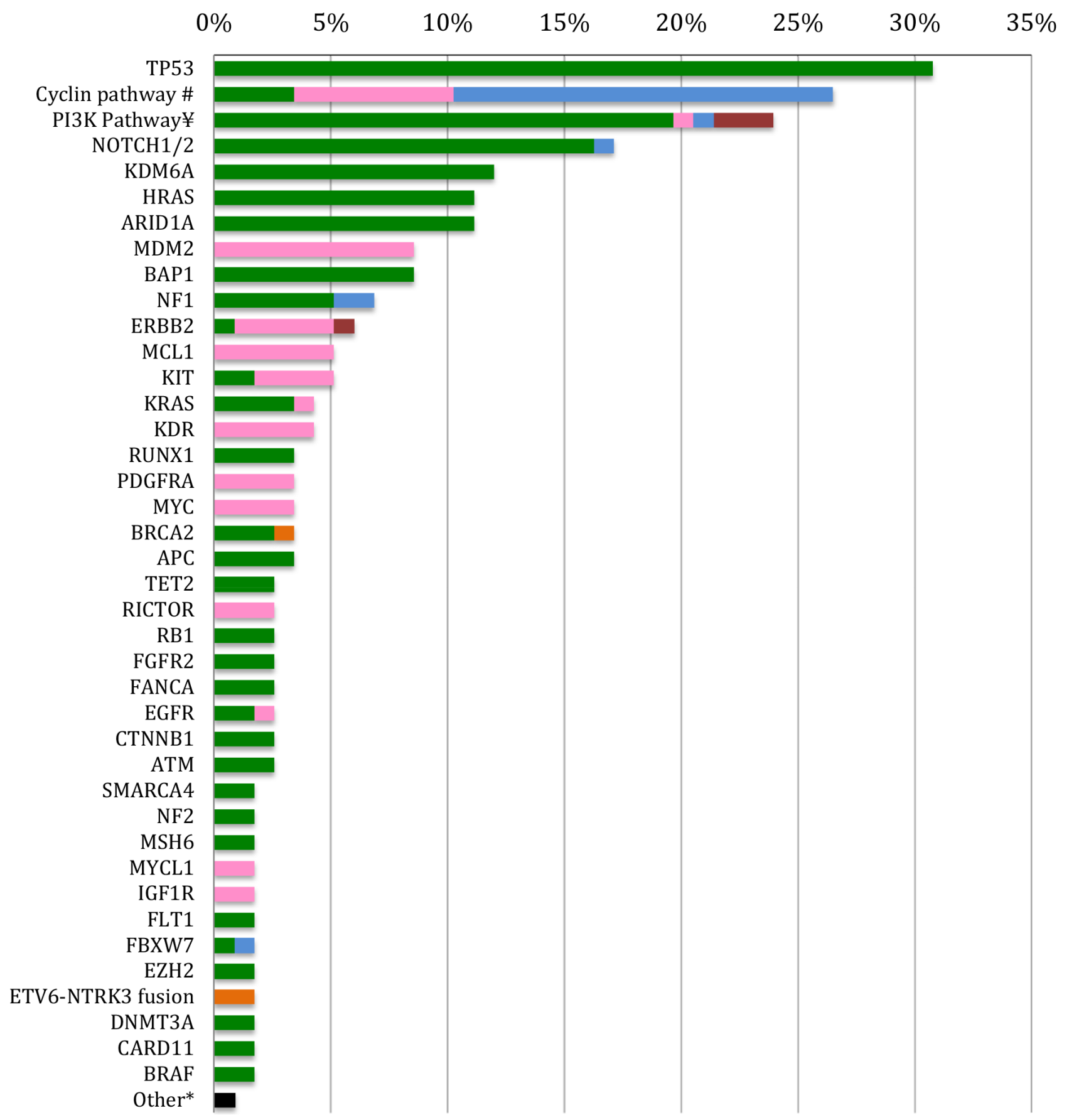

Mutation $\square$ Amplification $\quad$ Loss $\quad$ Fusion $\quad$ Multiple alteration

${ }^{\#}$ Cyclin pathway aberrations included CCND1, CDK4/6 or CDKN2A/B aberrations.

${ }^{\ddagger} \mathrm{PI} 3 \mathrm{~K}$ pathway aberrations included PIK3CA, PIK3R1, PTEN or AKT1/3 aberrations.

*Other: Genetic aberration with $N=1$. 
B. Frequently associated genetic aberrations in patients with adenoid cystic carcinoma $(N=49)$

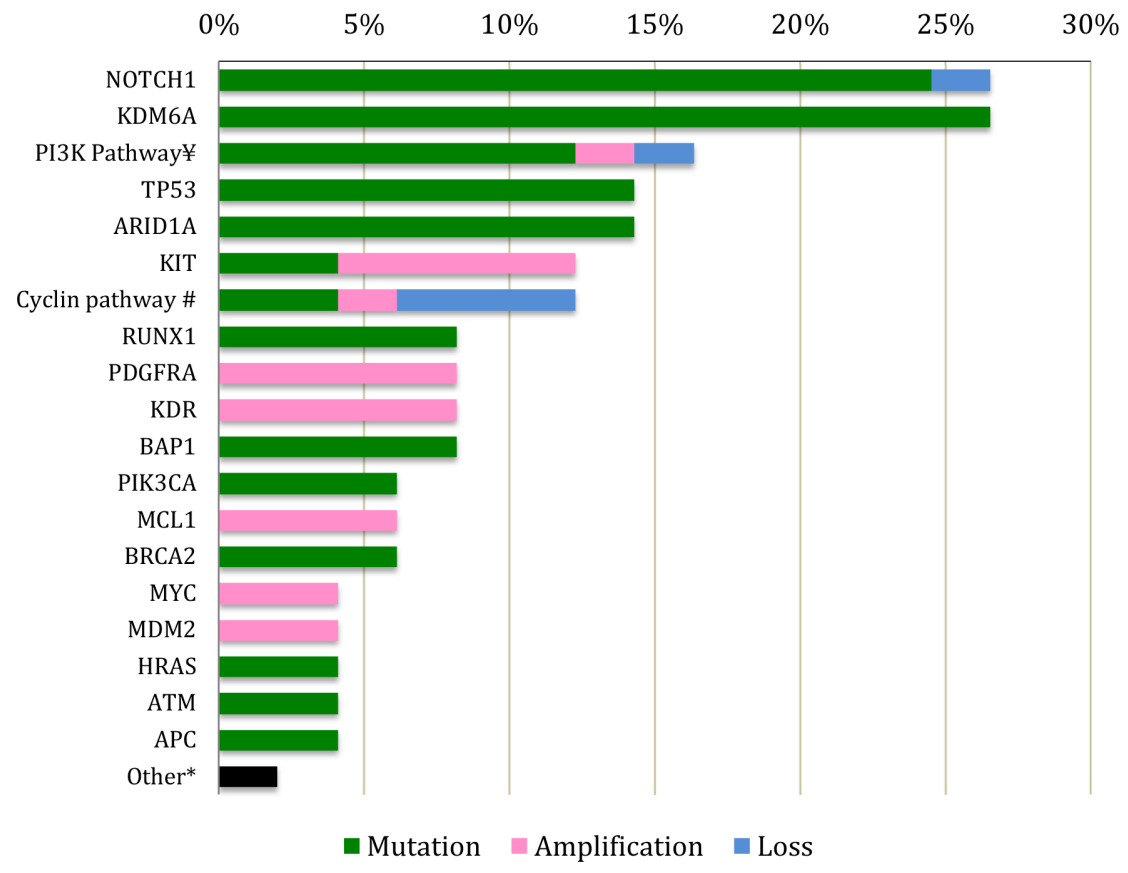

${ }^{\sharp} \mathrm{PI} 3 \mathrm{~K}$ pathway aberrations included PIK3CA, PIK3R1, PTEN or AKT1/3 aberrations. ${ }^{\#}$ Cyclin pathway aberrations included CCND1, CDK4/6 or CDKN2A/B aberrations.

*Other: Genetic aberration with $N=1$.

C. Frequently associated genetic aberrations in patients with salivary gland adenocarcinoma, not otherwise specified $(N=46)$

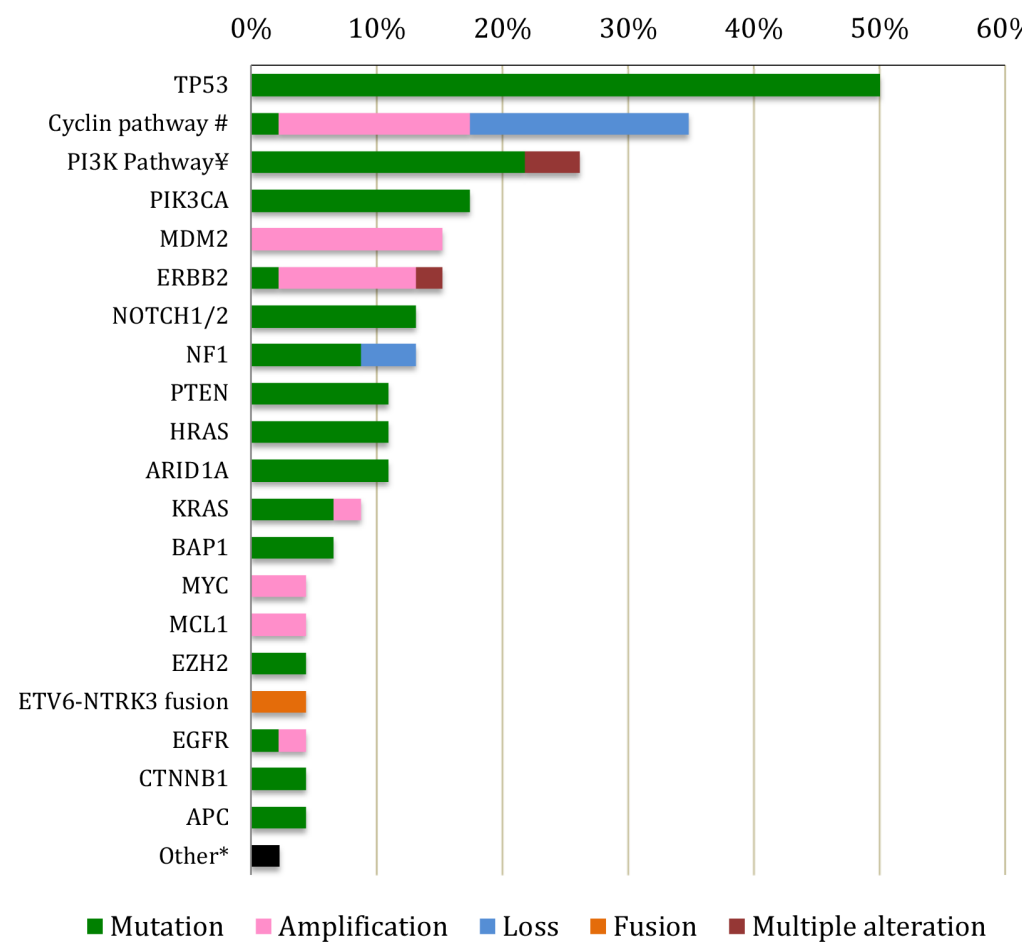

${ }^{*}$ Cyclin pathway aberrations included CCND1, CDK4/6 or CDKN2A/B aberrations.

${ }^{*} \mathrm{PI} 3 \mathrm{~K}$ pathway aberrations included PIK3CA, PIK3R1, PTEN or AKT1/3 aberrations.

* Other: Genetic aberration with $N=1$.

Figure 1: Genetic aberrations in patients with all salivary gland tumors $(N=117)$. (A) adenoid cystic carcinoma $(N=49)(B)$ and in patients with adenocarcinoma, not otherwise specified $(N=46)(C)$. 


\section{Number of all reported genetic aberrations per patient}

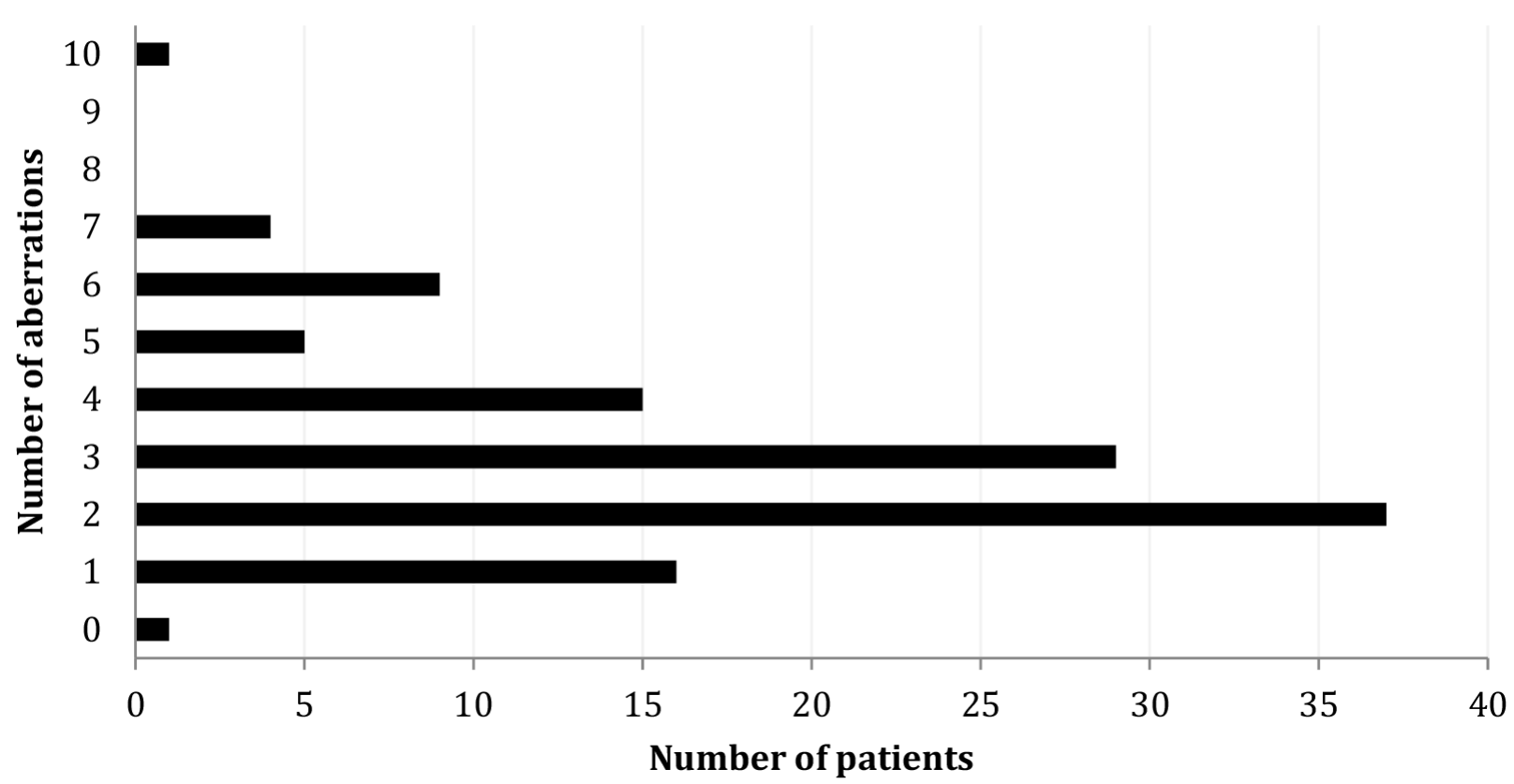

\section{Number of actionable genetic aberrations per patient}

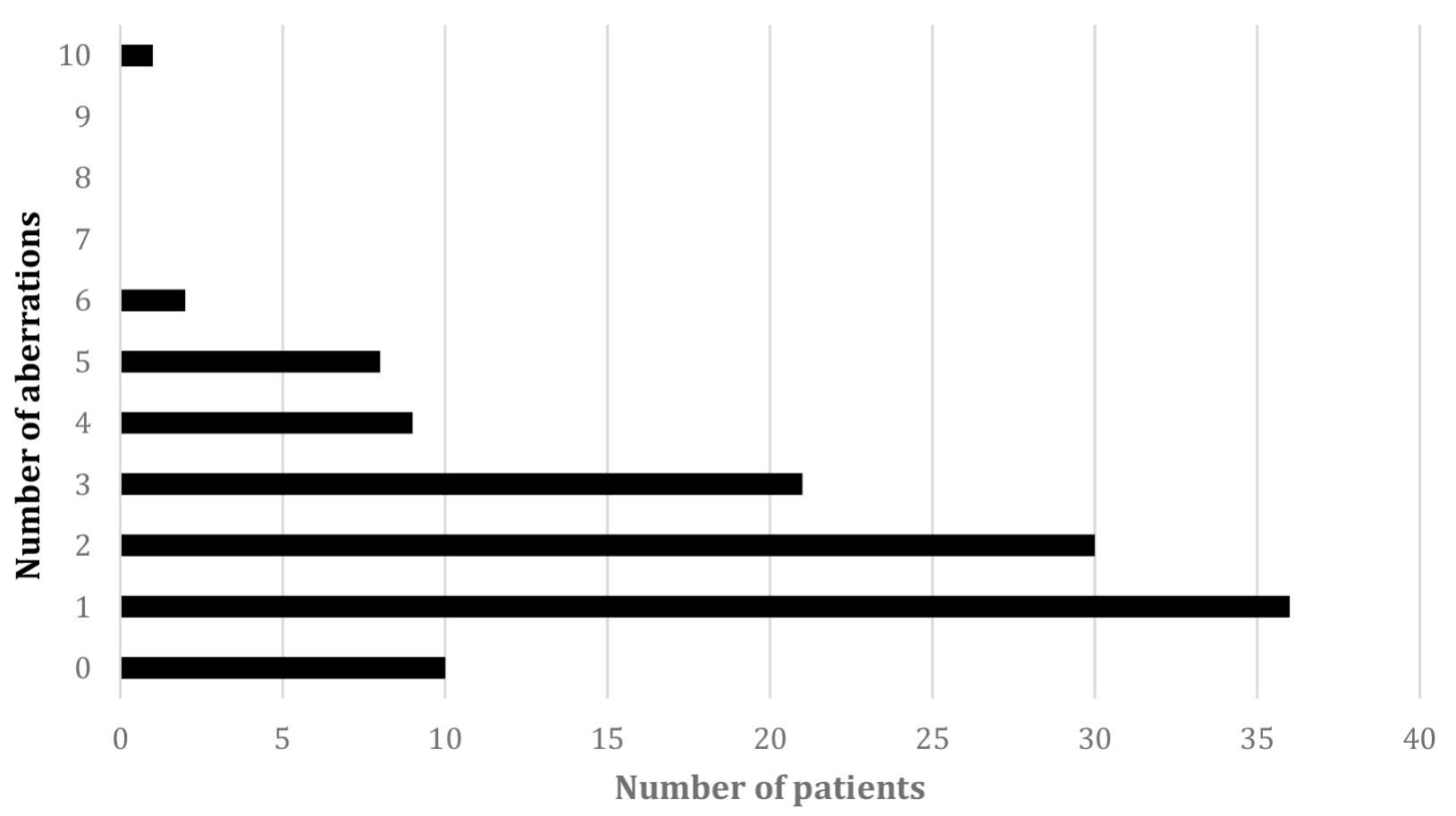

Figure 2: Number of reported genetic aberrations and number of theoretically actionable genetic aberrations per patient. Of the 354 total aberrations (some aberrations may have been found in more than one person), 257 were actionable, with 107/117 of patients $(91.5 \%)$ having a potentially actionable abnormality. Of the 240 distinct aberrations, 155 (64.6\%) were potentially actionable. An aberration was considered potentially actionable if there is a drug that is approved or in clinical trials that targets that aberration with low nM IC50 or an antibody that primarily targets that abnormality. 
Table 2: Association between TP53 aberration and co-existing molecular aberrations in patients with salivary gland tumors $(N=117)$

\begin{tabular}{|c|c|c|c|c|}
\hline $\begin{array}{l}\text { Patient characteristics } \\
N=117\end{array}$ & $\begin{array}{c}\text { Aberrant TP53 } \\
N=36(\%)\end{array}$ & $\begin{array}{c}\text { Normal TP53 } \\
N=81(\%)\end{array}$ & $\begin{array}{c}p \text {-value } \\
\text { Univariate }\end{array}$ & $\begin{array}{c}p \text {-value } \\
\text { Multivariate }\end{array}$ \\
\hline \multicolumn{5}{|l|}{ Co-existing aberrations ${ }^{\S}$} \\
\hline Cyclin pathway" & & & 0.82 & \\
\hline Aberrant $(N=31)$ & $10(32.3)$ & $21(67.7)$ & & \\
\hline Wild-type $(N=86)$ & $26(30.2)$ & $60(69.8)$ & & \\
\hline PI3K pathway ${ }^{*}$ & & & 0.06 & 0.04 \\
\hline Aberrant $(N=28)$ & $13(46.4)$ & $15(53.6)$ & & \\
\hline Wild-type $(N=89)$ & $23(25.8)$ & $66(74.2)$ & & \\
\hline NOTCH1/2 & & & 0.11 & \\
\hline Aberrant $(N=20)$ & $3(15.0)$ & $17(85.0)$ & & \\
\hline Wild-type $(N=97)$ & $33(34.0)$ & $64(66.0)$ & & \\
\hline PIK3CA & & & 0.25 & \\
\hline Aberrant $(N=16)$ & $7(43.8)$ & $9(56.3)$ & & \\
\hline Wild-type $(N=101)$ & $29(28.7)$ & $72(71.3)$ & & \\
\hline KDM6A & & & 0.55 & \\
\hline Aberrant $(N=14)$ & $3(21.4)$ & $11(78.6)$ & & \\
\hline Wild-type $(N=103)$ & $33(32.0)$ & $70(68.0)$ & & \\
\hline ARID1A & & & 0.75 & \\
\hline Aberrant $(N=13)$ & $3(23.1)$ & $10(76.9)$ & & \\
\hline Wild-type $(N=104)$ & $33(31.7)$ & $71(68.3)$ & & \\
\hline HRAS & & & 0.22 & \\
\hline Aberrant $(N=13)$ & $6(46.2)$ & $7(53.8)$ & & \\
\hline Wild-type $(N=104)$ & $30(28.8)$ & $74(71.2)$ & & \\
\hline BAP1 & & & 0.49 & \\
\hline Aberrant $(N=10)$ & $4(40.0)$ & $6(60.0)$ & & \\
\hline Wild-type $(N=107)$ & $32(29.9)$ & $75(70.1)$ & & \\
\hline MDM2 & & & 0.17 & \\
\hline Aberrant $(N=10)$ & $1(10.0)$ & $9(90.0)$ & & \\
\hline Wild-type $(N=107)$ & $35(32.7)$ & $72(67.3)$ & & \\
\hline NF1 & & & 0.01 & 0.07 \\
\hline Aberrant $(N=8)$ & $6(75.0)$ & $2(25.0)$ & & \\
\hline Wild-type $(N=109)$ & $30(27.5)$ & $79(72.5)$ & & \\
\hline ERBB2 & & & 0.003 & 0.01 \\
\hline Aberrant $(N=7)$ & $6(85.7)$ & $1(14.3)$ & & \\
\hline Wild-type $(N=110)$ & $30(27.3)$ & $80(72.7)$ & & \\
\hline
\end{tabular}

" $p$-values are from Fisher's exact test.

" $p<0.1$ from univariate analysis were included in multivariate analysis using multiple logistic regression models.

\$Included characteristics with $N \geq 7$ of genetic aberration.

${ }^{\#}$ Cyclin pathway aberrations included $C C N D 1, C D K 4 / 6$ or $C D K N 2 A / B$ aberrations.

${ }^{*}$ PI3K pathway aberrations included PIK3CA, PIK3R1, PTEN or $A K T 1 / 3$ aberrations. 
pathway (PIK3CA, PIK3R1, PTEN or AKT1/3) were also found to be associated with TP53 aberrations (13 of 28 patients [46.4\%] with anomalies in PI3K pathway had a TP53 aberration; 23 of 89 patients [25.8\%] with normal PI3K pathway had a TP53 aberration; $p=0.06$ [trend]). Interestingly, $E R B B 2$ aberrations were also associated with TP53 aberrations (6 of 7 patients [85.7\%] with aberrant ERBB2 had a TP53 aberration; 30 of 110 patients [27.3\%] with normal ERBB2 had a TP53 aberration; $p=0.003$ ).

After multivariate analysis, anomalies in the PI3K pathway and $E R B B 2$ aberrations were found to have an increased association with TP53 aberrations ( $p=0.04$ and 0.01 respectively) (Table 2$)$.

\section{Association between aberrant cyclin pathway (CCND1, CDK4/6 or $C D K N 2 A / B$ ) and co-existing molecular aberrations. Univariate and multivariate analysis (Table 3 )}

In univariate analysis, there was a negative association between aberrant cyclin pathway and aberrant NOTCH1/2 (2 of 20 patients [10.0\%] with aberrant NOTCH1/2 had an abnormality in cyclin pathway; 29 of 97 patients [29.9\%] with normal NOTCH1/2 had an abnormality in cyclin pathway; $p=0.09$ [trend]). Presence of an MDM2 aberration was associated with abnormalities in cyclin pathway by univariate analysis (6 of 10 patients [60.0\%] with aberrant MDM2 had an abnormality in cyclin pathway; 25 of 107 patients [23.4\%] with normal MDM2 had an abnormality in cyclin pathway; $p=0.02$ ).

After multivariate analysis, aberrations in $M D M 2$ remain positively associated with an aberrant cyclin pathway $(p=0.03)$ (Table 3$)$.

\section{Association between PI3K pathway abnormalities (PIK3CA, PTEN, AKT1/3 aberrations) and co-existing molecular aberrations. Univariate and multivariate analysis (Table 4)}

In univariate analysis, aberrations in HRAS were associated with PI3K pathway abnormalities (10 of 13 patients [76.9\%] with aberrant HRAS had a PI3K pathway abnormality; 18 of 104 patients [17.3\%] with normal HRAS had a PI3K pathway abnormality; $p=<0.0001)$.

A trend toward an association between aberrations in $N F 1$ and PI3K pathway abnormalities was noted (4 of 8 patients [50.0\%] with aberrant $N F 1$ had an abnormality in the PI3K pathway; 24 of 109 patients [22.0\%] with normal NF1 had an abnormality in PI3K pathway; $p=0.09$ [trend]). As mentioned earlier (Table 2), there was a positive correlation between PI3K pathway abnormalities and aberrant TP53 (13 of 36 patients [36.1\%] with aberrant TP53 had an abnormality in the PI3K pathway; 15 of 81 patients [18.5\%] with normal TP53 had an abnormality in the PI3K pathway; $p=0.06$ [trend]).

The correlation between aberrant TP53 and PI3K pathway was no longer seen after multivariate analysis (Tables 2 and 4). However, the association between aberrant $H R A S$ and PI3K pathway abnormalities remained statistically significant ( $p=0.0001)$ (Table 4$)$.

\section{DISCUSSION}

Malignant salivary gland tumors are an uncommon type of cancer of the head and neck [1, 2]. In general, salivary gland tumors have shown low response rates to chemotherapies [7-10] or to molecularly targeted therapies that are administered without molecular matching [11-13, $15,16,18-22]$. Thus, therapeutic options for salivary gland tumors are limited. However, anecdotal reports have described remarkable responses in salivary tumors when genetic aberrations and therapies were matched: trastuzumab and lapatinib for Her2-aberrant salivary tumors [23] or mTOR inhibitors for PIK3CA-aberrant neoplasms [24]. We therefore investigated the genomic landscape of salivary gland tumors by targeted nextgeneration sequencing.

In our current study of 117 patients suffering from salivary gland tumors, the most common histological diagnosis was adenoid cystic carcinoma (41.9\% [49/117]). The second most common histology was adenocarcinoma, NOS (39.3\% [46/117]) followed by acinic cell carcinoma $(6.0 \%$ [7/117]) and mucoepidermoid carcinoma (4.3\% [5/117]) (Table 1).

It is unclear why the frequency of histological subtypes of salivary gland tumors seen in this study is different from the previous literature; mucoepidermoid carcinoma and adenoid cystic carcinoma are the two most common subtypes $[4,5]$ and adenocarcinoma, NOS has been reported to be relatively low in frequency $(1.8-3.3 \%)$ $[4,5]$. However it is plausible that aggressive histological subtypes of malignant salivary gland tumors are more frequently referred for next-generation sequencing in order to pursue possible treatment options. Indeed, Wahlberg et al reported that patients with adenocarcinoma, NOS had worse 10-year survival compared to mucoepidermoid and adenoid cystic carcinoma (10-year survival 55\%, 80\%, and $74 \%$ respectively) [3].

The most common genetic aberration among 117 patients with salivary gland tumors was TP53 mutation (36/117 [30.8\%]) (Table 1, Figure 1A and Supplemental Table 1). Our current study is in agreement with previous reports demonstrating that $22-60 \%$ of salivary gland tumors harbor a TP53 mutation [25-27]. Although little is known about the role of TP53 in the pathogenesis 
Table 3: Association between aberrant cyclin pathway (CCND1, $C D K 4 / 6$ or $C D K N 2 A / B)$ and co-existing molecular aberration in patients with salivary gland tumor $(N=117)$

\begin{tabular}{|c|c|c|c|c|}
\hline $\begin{array}{l}\text { Patient characteristics } \\
N=117\end{array}$ & $\begin{array}{c}\text { Aberrant cyclin } \\
\text { pathway } \\
N=31(\%)\end{array}$ & $\begin{array}{c}\text { Normal cyclin } \\
\text { pathway } N=86(\%)\end{array}$ & $\begin{array}{l}p \text {-value } \\
\text { Univariate }\end{array}$ & $\begin{array}{c}p \text {-value } \\
\text { Multivariate }\end{array}$ \\
\hline \multicolumn{5}{|l|}{ Co-existing aberrations ${ }^{\S}$} \\
\hline TP53 & & & 0.82 & \\
\hline Aberrant $(N=36)$ & $10(27.8)$ & $26(72.2)$ & & \\
\hline Wild-type $(N=81)$ & $21(25.9)$ & $60(74.1)$ & & \\
\hline PI3K pathway & & & 0.33 & \\
\hline Aberrant $(N=28)$ & $5(17.9)$ & $23(82.1)$ & & \\
\hline Wild-type $(N=89)$ & $26(29.2)$ & $63(70.8)$ & & \\
\hline NOTCH1/2 & & & 0.09 & 0.10 \\
\hline Aberrant $(N=20)$ & $2(10.0)$ & $18(90.0)$ & & \\
\hline Wild-type $(N=97)$ & $29(29.9)$ & $68(70.1)$ & & \\
\hline PIK3CA & & & 0.55 & \\
\hline Aberrant $(N=16)$ & $3(18.8)$ & $13(81.3)$ & & \\
\hline Wild-type $(N=101)$ & $28(27.7)$ & $73(72.3)$ & & \\
\hline KDM6A & & & 0.11 & \\
\hline Aberrant $(N=14)$ & $1(7.1)$ & $13(92.9)$ & & \\
\hline Wild-type $(N=103)$ & $30(29.1)$ & $73(70.9)$ & & \\
\hline ARID1A & & & 0.18 & \\
\hline Aberrant $(N=13)$ & $1(7.7)$ & $12(92.3)$ & & \\
\hline Wild-type $(N=104)$ & $30(28.8)$ & $74(71.2)$ & & \\
\hline HRAS & & & 0.18 & \\
\hline Aberrant $(N=13)$ & $1(7.7)$ & $12(92.3)$ & & \\
\hline Wild-type $(N=104)$ & $30(28.8)$ & $74(71.2)$ & & \\
\hline BAP1 & & & 0.45 & \\
\hline Aberrant $(N=10)$ & $4(40.0)$ & $6(60.0)$ & & \\
\hline Wild-type $(N=107)$ & $27(25.2)$ & $80(74.8)$ & & \\
\hline MDM2 & & & 0.02 & 0.03 \\
\hline Aberrant $(N=10)$ & $6(60.0)$ & $4(40.0)$ & & \\
\hline Wild-type $(N=107)$ & $25(23.4)$ & $82(76.6)$ & & \\
\hline NF1 & & & 0.68 & \\
\hline Aberrant $(N=8)$ & $1(12.5)$ & $7(87.5)$ & & \\
\hline Wild-type $(N=109)$ & $30(27.5)$ & $79(72.5)$ & & \\
\hline ERBB2 & & & 1.00 & \\
\hline Aberrant $(N=7)$ & $2(28.6)$ & $5(71.4)$ & & \\
\hline Wild-type $(N=110)$ & $29(26.4)$ & $81(73.6)$ & & \\
\hline
\end{tabular}

${ }^{*} p$-values are from Fisher's exact test.

${ }^{7} p<0.1$ from univariate analysis were included in multivariate analysis using multiple logistic regression models.

${ }^{\$}$ Included characteristics with $N \geq 7$ of genetic aberration.

${ }^{*}$ PI3K pathway aberrations included PIK3CA, PIK3R1, PTEN or AKT1/3 aberrations. 
Table 4: Association between PI3K pathway abnormalities (PIK3, PIK3R1, PTEN, or AKT1/3 aberrations) and co-existing molecular aberration in patients with salivary gland tumor $(N=117)$

\begin{tabular}{|c|c|c|c|c|}
\hline $\begin{array}{l}\text { Patient characteristics } \\
N=117\end{array}$ & $\begin{array}{c}\text { Aberrant PI3K } \\
\text { pathway } N=28(\%)\end{array}$ & $\begin{array}{c}\text { Normal PI3K } \\
\text { pathway } N=89(\%)\end{array}$ & $\begin{array}{l}p \text {-value } \\
\text { Univariate }\end{array}$ & $\begin{array}{c}p \text {-value } \\
\text { Multivariate }\end{array}$ \\
\hline \multicolumn{5}{|l|}{ Co-existing aberrations ${ }^{\S}$} \\
\hline TP53 & & & 0.06 & 0.22 \\
\hline Aberrant $(N=36)$ & $13(36.1)$ & $23(63.9)$ & & \\
\hline Wild-type $(N=81)$ & $15(18.5)$ & $66(81.5)$ & & \\
\hline Cyclin pathway & & & 0.33 & \\
\hline Aberrant $(N=31)$ & $5(16.1)$ & $26(83.9)$ & & \\
\hline Wild-type $(N=86)$ & $23(26.7)$ & $63(73.3)$ & & \\
\hline NOTCH1/2 & & & 0.15 & \\
\hline Aberrant $(N=20)$ & $2(10.0)$ & $18(90.0)$ & & \\
\hline Wild-type $(N=97)$ & $26(26.8)$ & $71(73.2)$ & & \\
\hline KDM6A & & & 0.51 & \\
\hline Aberrant $(N=14)$ & $2(14.3)$ & $12(85.7)$ & & \\
\hline Wild-type $(N=103)$ & $26(25.2)$ & $77(74.8)$ & & \\
\hline ARID1A & & & 0.19 & \\
\hline Aberrant $(N=13)$ & $1(7.7)$ & $12(92.3)$ & & \\
\hline Wild-type $(N=104)$ & $27(26.0)$ & $77(74.0)$ & & \\
\hline HRAS & & & $<0.0001$ & 0.0001 \\
\hline Aberrant $(N=13)$ & $10(76.9)$ & $3(23.1)$ & & \\
\hline Wild-type $(N=104)$ & $18(17.3)$ & $86(82.7)$ & & \\
\hline BAP1 & & & 0.70 & \\
\hline Aberrant $(N=10)$ & $3(30.0)$ & $7(70.0)$ & & \\
\hline Wild-type $(N=107)$ & $25(23.4)$ & $82(76.6)$ & & \\
\hline MDM2 & & & 1.00 & \\
\hline Aberrant $(N=10)$ & $2(20.0)$ & $8(80.0)$ & & \\
\hline Wild-type $(N=107)$ & $26(24.3)$ & $81(75.7)$ & & \\
\hline NF1 & & & 0.09 & 0.16 \\
\hline Aberrant $(N=8)$ & $4(50.0)$ & $4(50.0)$ & & \\
\hline Wild-type $(N=109)$ & $24(22.0)$ & $85(78.0)$ & & \\
\hline ERBB2 & & & 1.00 & \\
\hline Aberrant $(N=7)$ & $1(14.3)$ & $6(85.7)$ & & \\
\hline Wild-type $(N=110)$ & $27(24.5)$ & $83(75.5)$ & & \\
\hline
\end{tabular}

" $p$-values are from Fisher's exact test.

I $p<0.1$ from univariate analysis were included in multivariate analysis using multiple logistic regression models.

\$Included characteristics with $N \geq 7$ of genetic aberration.

${ }^{\#}$ Cyclin pathway aberrations included $C C N D 1, C D K 4 / 6$ or $C D K N 2 A / B$ aberrations. 
of salivary gland tumors, it has been suggested that alteration in this gene is involved in later stages of tumor progression [28]. Of interest, Said et al showed that bevacizumab-containing regimens were associated with longer progression-free survival (PFS) when compared to non-bevacizumab-containing regimens in patients with TP53-mutated advanced solid tumors (median 11.0 versus 4.0 months; PFS was not increased in patients with wild-type TP53 on bevacizumab-based treatment [median $=5$ months, $p<0.0001]$ ] [29]. These results require validation in a prospective study. Of interest, in our study, aberrations in ERBB2 were associated with TP53 anomalies after multivariate analysis $(p=0.01)$ (Table 2). Anomalies in ERBB2 may be targeted with lapatinib or trastuzumab $[23,30]$.

The second most common aberrations involved the cyclin pathway (CCND1, CDK4/6 or $C D K N 2 A / B)$, which was abnormal in $26.5 \%$ of patients $(31 / 117)$ with salivary gland tumors. Aberrations in the cyclin D-cyclin-dependent kinase pathway that regulates the cell cycle restriction point is a common feature of human cancer, contributing to tumor proliferation, genomic instability and chromosomal instability [31-33]. This pathway can be altered through multiple mechanisms including increased signaling through $C D K 4$ and $C D K 6$ amplification, overexpression of cyclin D1, and loss of inhibitors including $C D K N 2 A$ (p16) and/or $C D K N 2 B$ (p15) [34-37]. Mutation or loss of $R B 1$ $(\mathrm{Rb}$; retinoblastoma) also alters this pathway, but renders tumors resistant to CDK inhibitors. Only three patients in our series had RBI mutations. According to Etges et al [38], malignant salivary gland tumors expressed the cyclin pathway differently from normal salivary gland when assessed by immunohistochemistry. They reported that expression of cyclin D1, CDK4 and CDKN2A were significantly higher in malignant salivary gland tumors (including adenoid cystic carcinoma and mucoepidermoid carcinoma) when compared to normal salivary gland. Meanwhile protein expression level of $\mathrm{Rb}$ was lower in malignant salivary gland tumors when compared to normal salivary gland [38]. Although it is unclear why CDKN2A protein expression was higher in malignant salivary gland tumors in this study, it is possible that the cyclin pathway is involved in tumorigenesis of salivary gland cancers. Regarding therapeutic implications, the cyclin pathway is possibly targetable with CDK4/6 inhibitors such as with palbociclib [33] and further investigation is warranted. Of interest, $M D M 2$ amplifications were more likely to be associated with abnormalities in the cyclin pathway $(6 / 10[60.0 \%]$ versus $25 / 107$ [23.4\%]; $p=0.03$ after multivariate analysis) (Table 3). Similarly, Moller et al reported that five out of seven patients with diffuse large B cell lymphomas had co-aberrations in $M D M 2$ (amplification) and $C D K N 2 A$ (deletion), when assessed by immunohistochemistry and polymerase chain reaction respectively [39]. Since MDM2 is negatively regulated by $C D K N 2 A, M D M 2$ amplification and aberrations in the cyclin pathway will likely lead to suppression of TP53 (TP53 is negatively regulated by MDM2) [40]. Thus, for patients with co-aberrations in $M D M 2$ and the CDK pathway, inhibition of both MDM2 [41] and the cyclin pathway [33] may be required to effectively target this pathway.

Importantly, aberrations in the PI3K pathway (PIK3CA, PIK3R1, PTEN or AKT) were commonly seen in salivary gland tumors (28/117 [23.9\%]). Of interest, there was a statistically significant association between aberrant HRAS and PI3K pathway abnormalities (10/13 [76.9\%] versus $18 / 104[17.3 \%] ; p=0.0001$ after multivariate analysis, Table 4). PI3K and RAS are key regulators of cell motility and chemotaxis and they influence each other's activities by direct and indirect feedback processes [42]. Janku et al have also previously shown that MAP (mitogen-activated protein) kinase-related genes are more frequently aberrant in the presence PIK3CA mutations than when PIK3CA is normal [43]. Since mutation in $H R A S$ is also capable of activating the MAP kinase signaling pathway, merely blocking the PI3K pathway will likely not be sufficient. Although the role of PIK3CA mutation as a predictive biomarker for everolimus or PI3K inhibitor response is controversial [44], the PI3K pathway is potentially targetable with the mTOR inhibitor everolimus [45]. Adding MEK inhibitors such as trametanib [46] in order to block signals downstream of HRAS may be required in patients who have anomalies in the PI3K pathway.

Our results in adenoid cystic carcinoma (Figure 1B) are in agreement with previously reported literature where several aberrations including NOTCH1/2 (3/24 [12.5\%]), KDM6A (2/24 [8.3\%]), CDKN2A (1/24 [4.2\%]) and PIK3CA (1/24 [4.2\%]) were identified by whole exome sequencing of 24 patients with adenoid cystic carcinoma [47]. Both studies had small numbers of patients, reflecting the rarity of this tumor.

Interestingly, $107 / 117$ patients $(91.5 \%)$ had potentially actionable aberrations (Supplemental Table 1). The number of actionable genes affected per patient ranged between zero and ten, with a median of two per patient (Figure 2). Of the 240 distinct aberrations, 155 (64.6\%) were potentially actionable. Of these 155 actionable aberrations, 114 were targetable by an FDA-approved drug (off label) (representing 47.5\% [114/240] of all distinct alterations). An additional 41 (17.1\% [41/240] of all distinct alterations) were targetable by an experimental drug in a clinical trial. (Figure 2, Supplemental Table 1 and 2). Overall, 91.5\% (107/117) of patients had at least one potentially actionable anomaly. As there are no FDAapproved targeted therapies for salivary gland tumors and most conventional chemotherapy has been shown to be associated with poor clinical outcomes (median overall survival [OS]: 4 to 21 months in the advanced setting) [7-10], targeted therapies based on molecular profiling merit investigation [48]. 
Our current study has some limitations. First, it was performed retrospectively with a relatively limited number of patients, especially in certain subgroups of salivary gland tumors. The small numbers preclude definitive statistical conclusions in some areas. Second, multiple comparisons could result in overcalling the implications of positive $p$ values. Third, we included heterogeneous salivary gland tumors. Fourth, molecular analysis was performed on archival tumor tissue, which was obtained at a different time points in relationship to the clinical history. Lastly, lumping the common pathway abnormalities together such as cyclin pathway (CCND1, $C D K 4 / 6$ or $C D K N 2 A / B)$ and PI3K pathway (PIK3CA, PIK3R1, PTEN or $A K T 1 / 3$ ) aberrations may be misleading since different mutations can lead to diverse functional consequences. However, despite these limitations, this genomic characterization of salivary gland tumors has uncovered some interesting and clinically relevant results.

In conclusion, our 117 patients with salivary gland malignancies harbored 354 alterations (median $=3$ per patient), 240 of which were distinct aberrations. The most common aberrations in patients with salivary gland tumors were in the TP53 gene, followed by alterations in the cyclin pathway and the PI3K pathway (PIK3CA, PIK3R1, PTEN or AKT) (Table 1 and Figure 1A). Interestingly, in multivariate analysis, there was a significant independent association between alterations in the TP53 and ERBB2 genes $(p=0.01)$ (Table 2), cyclin pathway and the MDM2 gene $(p=0.03)$ (Table 3$)$, and between HRAS and the PI3K pathway ( $p=0.0001$ ) (Table 4$)$, suggesting that dual targeting with cognate inhibitors may be necessary to overcome resistance. The vast majority of patients $(91.5 \%)$ had at least one aberration that was potentially targetable by an FDA-approved drug or an investigational agent in a clinical trial. Indeed, of the 240 distinct aberrations, 155 (64.6\%) were potentially actionable. These observations suggest that matching patients with appropriately targeted agents is feasible and warrants study. However, only 10 of 117 patients $(8.5 \%)$ had a molecular portfolio identical to at least one other patient. The latter results are similar to those that we reported in metastatic breast cancer, where we recently described 131 distinct aberrations in 57 patients with no two patients having the same molecular portfolio [49-51]. Taken together, these observations suggest that customized combination therapy may have the potential to provide significant benefit for these patients.

\section{MATERIALS AND METHODS}

\section{Patients}

We investigated the genomic aberration status of patients with salivary gland tumors referred to Foundation Medicine (Cambridge, MA) for NGS from October
2011 to November $2013(N=117)$. We retrospectively reviewed the histological types of salivary gland tumors and associated genetic aberrations. Here, we report on the prevalence and frequencies of these aberrations in salivary gland tumors.

\section{Tissue samples and mutational analysis}

Available tissues from diagnostic and therapeutic procedures were used to assess molecular aberrations. Samples from formalin-fixed paraffin-embedded tissue were sent for targeted NGS at Foundation Medicine (Cambridge, MA). The test sequences the entire coding sequence of 182 , or more recently 236 , cancer-related genes plus 47 introns from 19 genes often rearranged or altered in cancer to an average depth-of-coverage of greater than 250X (http://foundationone.com/docs/ FoundationOne_tech-info-and-overview.pdf).

This method of sequencing allows for detection of copy number alterations, gene rearrangements, and somatic mutations with $99 \%$ specificity and $>99 \%$ sensitivity for base substitutions at $\geq 5$ mutant allele frequency and $>95 \%$ sensitivity for copy number alterations. Foundation Medicine uses a threshold of $\geq 8$ copies for gene amplification. The submitting physicians provided specification of tumor types. Next-generation sequencing data were collected and interpreted by N-of-One, Inc. (Lexington, MA; http://www.n-of-one. com). Data was analyzed in accordance with UCSD IRB guidelines. For the purpose of our analysis, "phosphoinositide 3-kinase (PI3K) pathway" alterations included alterations of PIK3CA, PIK3RI, PTEN, or $A K T 1 / 3$. Similarly, "cyclin pathway" alterations included $C C N D 1, C D K 4 / 6$, or $C D K N 2 A / B$ alterations. We have evaluated if certain genomic aberrations were actionable or not based on the availability of drug that is approved or in clinical trials that targets that aberration with low nM IC50 or an antibody that primarily targets that abnormality.

\section{Endpoints and statistical methods}

Descriptive statistics were used to summarize the baseline patient characteristics. The Fisher's exact test was used to assess the association between categorical variables in univariate analysis. Multiple logistic regression models were used for multivariable analysis. All tests were 2-sided. Statistical analyses were carried out using GraphPad Prism version 6.0 (San Diego, CA, USA) and SPSS version 22.0 (Chicago, IL, USA).

\section{ACKNOWLEDGMENTS AND FUNDING}

This project was partially supported in part by the Joan and Irwin Jacobs Fund and My Answer To Cancer philanthropic fund. 


\section{CONFLICTS OF INTEREST}

Dr Kurzrock has received consultant fees from Sequenom and is a founder of RScueRX.

Sheryl K. Elkin, Brett N. Tomson, and Jennifer Levin Carter are employees of N-of-One, Inc., Lexington, MA.

\section{REFERENCES}

1. Barnes L, World Health Organization and International Agency for Research on Cancer. (2005). Pathology and genetics of head and neck tumours: World Health Organization.

2. Guzzo M, Locati LD, Prott FJ, Gatta G, McGurk M and Licitra L. Major and minor salivary gland tumors. Crit Rev Oncol Hematol. 2010; 74:134-148.

3. Wahlberg P, Anderson H, Biorklund A, Moller T and Perfekt R. Carcinoma of the parotid and submandibular glands--a study of survival in 2465 patients. Oral Oncol. 2002; 38:706-713.

4. Al-Khiro FI. Salivary gland tumors: A review of 171 cases, with particular reference to histological types, site, age and gender distribution. Journal of Baghdad College of Dentistry. 2014; 26:88-91.

5. Jones AV, Craig GT, Speight PM and Franklin CD. The range and demographics of salivary gland tumours diagnosed in a UK population. Oral Oncol. 2008; 44:407-417.

6. Laurie SA and Licitra L. Systemic therapy in the palliative management of advanced salivary gland cancers. J Clin Oncol. 2006; 24:2673-2678.

7. Licitra L, Marchini S, Spinazze S, Rossi A, Rocca A, Grandi $\mathrm{C}$ and Molinari R. Cisplatin in advanced salivary gland carcinoma. A phase II study of 25 patients. Cancer. $1991 ; 68: 1874-1877$.

8. Gilbert J, Li Y, Pinto HA, Jennings T, Kies MS, Silverman P and Forastiere AA. Phase II trial of taxol in salivary gland malignancies (E1394): a trial of the Eastern Cooperative Oncology Group. Head Neck. 2006; 28:197-204.

9. Airoldi M, Garzaro M, Pedani F, Ostellino O, Succo G, Riva G, Sensini M, Naqe N, Bellini E, Raimondo L and Pecorari G. Cisplatin+Vinorelbine Treatment of Recurrent or Metastatic Salivary Gland Malignancies (RMSGM): A Final Report on 60 Cases. Am J Clin Oncol. 2014.

10. Licitra L, Cavina R, Grandi C, Palma SD, Guzzo M, Demicheli R and Molinari R. Cisplatin, doxorubicin and cyclophosphamide in advanced salivary gland carcinoma. A phase II trial of 22 patients. Ann Oncol. 1996; 7:640-642.

11. Holst VA, Marshall CE, Moskaluk CA and Frierson HF, Jr. KIT protein expression and analysis of c-kit gene mutation in adenoid cystic carcinoma. Mod Pathol. 1999; 12:956-960.
12. Vered $\mathrm{M}$, Braunstein $\mathrm{E}$ and Buchner A. Immunohistochemical study of epidermal growth factor receptor in adenoid cystic carcinoma of salivary gland origin. Head Neck. 2002; 24:632-636.

13. Glisson B, Colevas AD, Haddad R, Krane J, El-Naggar A, Kies M, Costello R, Summey C, Arquette M, Langer C, Amrein PC and Posner M. HER2 expression in salivary gland carcinomas: dependence on histological subtype. Clin Cancer Res. 2004; 10:944-946.

14. Jaehne M, Roeser K, Jaekel T, Schepers JD, Albert N and Loning T. Clinical and immunohistologic typing of salivary duct carcinoma: a report of 50 cases. Cancer. 2005; 103:2526-2533.

15. Nasser SM, Faquin WC and Dayal Y. Expression of androgen, estrogen, and progesterone receptors in salivary gland tumors. Frequent expression of androgen receptor in a subset of malignant salivary gland tumors. Am J Clin Pathol. 2003; 119:801-806.

16. Nardi V, Sadow PM, Juric D, Zhao D, Cosper AK, Bergethon K, Scialabba VL, Batten JM, Borger DR, Iafrate AJ, Heist RS, Lawrence DP, Flaherty KT, Bendell JC, Deschler D, Li Y, et al. Detection of novel actionable genetic changes in salivary duct carcinoma helps direct patient treatment. Clin Cancer Res. 2013; 19:480-490.

17. Fan CY, Melhem MF, Hosal AS, Grandis JR and Barnes EL. Expression of androgen receptor, epidermal growth factor receptor, and transforming growth factor alpha in salivary duct carcinoma. Arch Otolaryngol Head Neck Surg. 2001; 127:1075-1079.

18. Pfeffer MR, Talmi Y, Catane R, Symon Z, Yosepovitch A and Levitt M. A phase II study of Imatinib for advanced adenoid cystic carcinoma of head and neck salivary glands. Oral Oncol. 2007; 43:33-36.

19. Jakob JA, Kies MS, Glisson BS, Kupferman ME, Liu DD, Lee JJ, El-Naggar AK, Gonzalez-Angulo AM and Blumenschein GR. A Phase II study of Gefitinib in Patients with Advanced Salivary Gland Cancers. Head Neck. 2014.

20. Locati LD, Bossi P, Perrone F, Potepan P, Crippa F, Mariani L, Casieri P, Orsenigo M, Losa M, Bergamini C, Liberatoscioli C, Quattrone P, Calderone RG, Rinaldi G, Pilotti S and Licitra L. Cetuximab in recurrent and/or metastatic salivary gland carcinomas: A phase II study. Oral Oncol. 2009; 45:574-578.

21. Haddad R, Colevas AD, Krane JF, Cooper D, Glisson B, Amrein PC, Weeks L, Costello R and Posner M. Herceptin in patients with advanced or metastatic salivary gland carcinomas. A phase II study. Oral Oncol. 2003; 39(7):724-727.

22. Agulnik M, Cohen EW, Cohen RB, Chen EX, Vokes EE, Hotte SJ, Winquist E, Laurie S, Hayes DN, Dancey JE, Brown S, Pond GR, Lorimer I, Daneshmand M, Ho J, Tsao MS, et al. Phase II study of lapatinib in recurrent or metastatic epidermal growth factor receptor and/or erbB2 expressing adenoid cystic carcinoma and non adenoid cystic carcinoma malignant tumors of the salivary glands. J Clin Oncol. 2007; 25:3978-3984. 
23. Falchook GS, Lippman SM, Bastida CC and Kurzrock R. Human epidermal receptor 2-amplified salivary duct carcinoma: regression with dual human epidermal receptor 2 inhibition and anti-vascular endothelial growth factor combination treatment. Head Neck. 2014; 36:E25-27.

24. Piha-Paul SA, Cohen PR and Kurzrock R. Salivary duct carcinoma: targeting the phosphatidylinositol 3-kinase pathway by blocking mammalian target of rapamycin with temsirolimus. J Clin Oncol. 2011; 29:e727-730.

25. Augello C, Gregorio V, Bazan V, Cammareri P, Agnese V, Cascio S, Corsale S, Calo V, Gullo A, Passantino R, Gargano G, Bruno L, Rinaldi G, Morello V, Gerbino A, Tomasino RM, et al. TP53 and p16INK4A, but not H-KIRas, are involved in tumorigenesis and progression of pleomorphic adenomas. J Cell Physiol. 2006; 207:654-659.

26. Kishi M, Nakamura M, Nishimine M, Ikuta M, Kirita T and Konishi N. Genetic and epigenetic alteration profiles for multiple genes in salivary gland carcinomas. Oral Oncol. 2005; 41:161-169.

27. Kiyoshima T, Shima K, Kobayashi I, Matsuo K, Okamura K, Komatsu S, Rasul AM and Sakai H. Expression of p53 tumor suppressor gene in adenoid cystic and mucoepidermoid carcinomas of the salivary glands. Oral Oncol. 2001; 37:315-322.

28. Papadaki H, Finkelstein SD, Kounelis S, Bakker A, Swalsky PA and Kapadia SB. The role of p53 mutation and protein expression in primary and recurrent adenoid cystic carcinoma. Hum Pathol. 1996; 27:567-572.

29. Said R, Hong DS, Warneke CL, Lee JJ, Wheler JJ, Janku F, Naing A, Falchook GS, Fu S, Piha-Paul S, Tsimberidou AM and Kurzrock R. P53 mutations in advanced cancers: clinical characteristics, outcomes, and correlation between progression-free survival and bevacizumab-containing therapy. Oncotarget. 2013; 4:705-714.

30. Baselga J, Bradbury I, Eidtmann H, Di Cosimo S, de Azambuja E, Aura C, Gomez H, Dinh P, Fauria K, Van Dooren V, Aktan G, Goldhirsch A, Chang TW, Horvath Z, Coccia-Portugal M, Domont J, et al. Lapatinib with trastuzumab for HER2-positive early breast cancer (NeoALTTO): a randomised, open-label, multicentre, phase 3 trial. Lancet. 2012; 379:633-640.

31. Hanahan D and Weinberg RA. Hallmarks of cancer: the next generation. Cell. 2011; 144:646-674.

32. Malumbres M and Barbacid M. Cell cycle, CDKs and cancer: a changing paradigm. Nat Rev Cancer. 2009; 9:153-166.

33. Rocca A, Farolfi A, Bravaccini S, Schirone A and Amadori D. Palbociclib (PD 0332991) : targeting the cell cycle machinery in breast cancer. Expert Opin Pharmacother. 2014; 15:407-420.

34. Kato S, Schwaederle M, Daniels GA, Piccioni D, Kesari S, Bazhenova L, Shima K, Parker BA, Fanta P and Kurzrock R. Cyclin-Dependent Kinase Pathway
Aberrations in Diverse Malignancies: Clinical and Molecular Characteristics. Cell Cycle. 2015; 14:1252-1259.

35. Schwaederle M, Daniels GA, Piccioni DE, Fanta PT, Schwab RB, Shimabukuro KA, Parker BA and Kurzrock R. Cyclin alterations in diverse cancers: Outcome and co-amplification network. Oncotarget. Oncotarget. 2015; 6:3033-3042.

36. Shapiro GI. Cyclin-dependent kinase pathways as targets for cancer treatment. J Clin Oncol. 2006; 24(11):1770-1783.

37. Sheppard KE and McArthur GA. The cell-cycle regulator CDK4: an emerging therapeutic target in melanoma. Clin Cancer Res. 2013; 19:5320-5328.

38. Etges A, Nunes FD, Ribeiro $\mathrm{KC}$ and Araujo VC. Immunohistochemical expression of retinoblastoma pathway proteins in normal salivary glands and in salivary gland tumours. Oral Oncol. 2004; 40:326-331.

39. Moller MB, Ino Y, Gerdes AM, Skjodt K, Louis DN and Pedersen NT. Aberrations of the p53 pathway components p53, MDM2 and CDKN2A appear independent in diffuse large B cell lymphoma. Leukemia. 1999; 13:453-459.

40. Polager S and Ginsberg D. p53 and E2f: partners in life and death. Nat Rev Cancer. 2009; 9:738-748.

41. Khoo KH, Verma CS and Lane DP. Drugging the p53 pathway: understanding the route to clinical efficacy. Nat Rev Drug Discov. 2014; 13:217-236.

42. Yang HW, Shin MG, Lee S, Kim JR, Park WS, Cho KH, Meyer T and Heo WD. Cooperative activation of PI3K by Ras and Rho family small GTPases. Mol Cell. 2012; 47:281-290.

43. Janku F, Lee JJ, Tsimberidou AM, Hong DS, Naing A, Falchook GS, Fu S, Luthra R, Garrido-Laguna I and Kurzrock R. PIK3CA mutations frequently coexist with RAS and BRAF mutations in patients with advanced cancers. PLoS One. 2011; 6:e22769.

44. Loi S, Michiels S, Baselga J, Bartlett JM, Singhal SK, Sabine VS, Sims AH, Sahmoud T, Dixon JM, Piccart MJ and Sotiriou C. PIK3CA genotype and a PIK3CA mutationrelated gene signature and response to everolimus and letrozole in estrogen receptor positive breast cancer. PLoS One. 2013; 8:e53292.

45. Janku F, Hong DS, Fu S, Piha-Paul SA, Naing A, Falchook GS, Tsimberidou AM, Stepanek VM, Moulder SL, Lee JJ, Luthra R, Zinner RG, Broaddus RR, Wheler JJ and Kurzrock R. Assessing PIK3CA and PTEN in early-phase trials with PI3K/AKT/mTOR inhibitors. Cell Rep. 2014; 6:377-387.

46. Infante JR, Fecher LA, Falchook GS, Nallapareddy S, Gordon MS, Becerra C, DeMarini DJ, Cox DS, Xu Y, Morris SR, Peddareddigari VG, Le NT, Hart L, Bendell JC, Eckhardt G, Kurzrock R, et al. Safety, pharmacokinetic, pharmacodynamic, and efficacy data for the oral MEK inhibitor trametinib: a phase 1 dose-escalation trial. Lancet Oncol. 2012; 13:773-781. 
47. Stephens PJ, Davies HR, Mitani Y, Van Loo P, Shlien A, Tarpey PS, Papaemmanuil E, Cheverton A, Bignell GR, Butler AP, Gamble J, Gamble S, Hardy C, Hinton J, Jia M, Jayakumar A, et al. Whole exome sequencing of adenoid cystic carcinoma. J Clin Invest. 2013; 123:2965-2968.

48. Vidwans SJ, Turski ML, Janku F, Garrido-Laguna I, Munoz J, Schwab R, Subbiah V, Rodon J and Kurzrock R. A framework for genomic biomarker actionability and its use in clinical decision making. Oncoscience. 2014; $1: 614-623$.

49. Kurzrock R and Giles FJ. Precision Oncology for Patients with Advanced Cancer: The Challenges of Malignant Snowflakes. Cell Cycle. 2015; 14:2219-21.
50. Wheler JJ, Lee JJ and Kurzrock R. Unique Molecular Landscapes in Cancer: Implications for Individualized, Curated Drug Combinations. Cancer Res. 2014; 74:7181-4.

51. Wheler JJ, Parker BA, Lee JJ, Atkins JT, Janku F, Tsimberidou AM, Zinner R, Subbiah V, Fu S, Schwab R, Moulder S, Valero V, Schwaederle M, Yelensky R, Miller VA, Stephens MP, et al. Unique molecular signatures as a hallmark of patients with metastatic breast cancer: implications for current treatment paradigms. Oncotarget. 2014; 5:2349-2354. 